\title{
An Analysis of Chinese American Literature from the Perspective of Cultural Translation
}

\author{
Zhenyuan Chen \\ School of Foreign Languages, Yancheng Teachers University, Yancheng 224002, China. \\ E-mail: bluegrass31506@163.com
}

\begin{abstract}
The rise and development of Chinese-American literature is closely related to the socio-cultural context in which the subject of its creation resides. Because the works contain a lot of Chinese elements, the writing of Chinese American literature often entails translation from the perspective of cultural studies. This kind of translation does not refer to the simple conversion on linguistic level, but the adaptation of Chinese culture, Chinese history and Chinese experience, which is a kind of invisible cultural translation. Chinese American writers have applied Chinese traditional culture to their works and achieved success in the target audience, which provides effective solutions and rich experience for the dissemination of traditional Chinese culture. This paper intends to study Chinese American literature from the perspective of cultural translations, and its enlightenment on the dissemination of traditional Chinese culture overseas.
\end{abstract}

Keywords: Chinese American Literature,Cultural Translation,Cultural Turn.

\section{Chinese American literature}

Chinese American literature refers to works by writers who were born and educated in the United States to overseas Chinese or Chinese American families with English as their native language and as well as major writing language. These works take the social life of Chinese Americans and Chinese immigrants as the object of observation and creation, and embody the unique spirit and value of Chinese Americans.

Most of Chinese-American writers are the offspring of Chinese living in the United States, that is, the first generation of Chinese who immigrated and settled in the United States. Their feelings are deeply rooted in the United States, where they were born and raised, but they are also mixed with the pain and hatred since they have never been fully accepted by the American society. When the native Chinese writers write about the United States, they are essentially writing and expressing themselves.

\section{Cultural Turn in Translation Studies}

In 1990, the anthology "Translation, History and Culture" was published and in the introductory paper by André Lefevere and Susan Bassnett, they put forward the notion of "cultural turn" in translation studies (Bassnett \& Lefevere, 2001:123), which started a new school in the field of western translation theory - the cultural school. As opposed to the linguistics school, the school of cultural translation studies goes beyond language and is no longer confined to the study of words and texts, emphasizing that language is not the operational form of translation, but rather cultural information(Lefevere, 1992:13). Translation entails not only bilingual communication, but also a kind of cross-cultural communication. Language is the carrier and embodiment of different cultures, and therefore translation should focus on the interaction between translation and culture, the ways in which culture influences and restricts translation, and "the

Copyright (C) 2020 Zhenyuan Chen

doi: 10.18282/le.v9i6.1342

This is an open-access article distributed under the terms of the Creative Commons Attribution Non-Commercial License

(http://creativecommons.org/licenses/by-nc/4.0/), which permits unrestricted non-commercial use, distribution, and reproduction in any medium, provided the original work is properly cited. 
larger issues of context, history, and customs" (Lefevere, 1992:11). In cross-cultural communication, translators play an indispensable role. The study of translated works, in a certain sense, is the study of the interaction between different cultures.

Both translation studies and cultural studies are concerned primarily with of the question of power relations and text production (Bassnett \& Lefevere, 2001:135). Lawrence Venuti pointed out that every step in the translation process from the selection of foreign texts to the realization of translation strategies, to the editing, commentary and reading of translations - is tempered by the different cultural values that are common in the target language, and these values are always in a certain hierarchical order (Xie, 2018:251). Therefore, translation always falls into a set of power relations between the original text context and the target text context. The emergence and acceptance of translation cannot be separated from the specific historical and cultural context. For the translator, there are external constraints inside and outside the text. The study of cultural translation, from the micro point of view, is to study the process of translation in the treatment of cultural factors, while from the macro point of view, is to examine translation from the cultural level. The school of cultural translation studies combines translation studies with cultural studies, places translation in the socio-cultural context, studies its socio-cultural functions, and realizes the "translation turn" of cultural studies.

\section{Chinese American literature as the Product of Cultural Translation}

The concept of "cultural translation" was first proposed by Homi Baba, one of the leading post-colonial theorists. In his opinion, "cultural translation" does not refer to the translation between specific texts of two languages and cultures, but a unique post-colonial text that integrates translation into writing. It can be said that the creation process of ChineseAmerican writers is also a process of understanding and translating Chinese culture from their own unique perspective. The expression of Chinese culture in their works undoubtedly makes them cultural translators. They successfully transform Chinese cultural customs into literary forms that westerners can both understand and accept, opening a window for the Western world to get to know China. These works have strong national characteristics and embody the imagination and creativity of the author as well as the translator.The unique perspectives given by their dual identities makes this group better able to assume the role of cultural ambassadors. In order to further promote the spread of Chinese culture and enhance the international status of Chinese culture, it is necessary to have an accurate understanding of the creative/translation behavior patterns of Chinese American writers.

In the actual process of literary creation, cultural factors will have a great impact on the meaning of words and sentences in works. Therefore, it is not surprising that people gradually shift from linguistic equivalence to cultural translation studies when conducting translation studies. From the perspective of translation theory, cultural translation theory is obviously different from other translation theories. It mainly studies and discusses the relationship between target language culture and source language culture from a new perspective. It can be said that cultural translation is actually a weapon for some minority groups and mainstream groups to fight for equal social status.

It can be found from many works that cultural translation is the most prominent feature of Chinese American writers in the process of literary creation. In the cultural translation, Chinese-American writers usually follow two cultural translation principles: one is what Lawrence Venuti calls "domestication". It mainly means that in the actual cultural translation process, the author is influenced by the culture of the target language country and then rewrites the culture of the source language to some extent. The opposite principle is called "foreignization", which mainly refers to the author's efforts to maintain the cultural characteristics of the source language.

To some extent, Chinese-American literature is a form of cultural translation. Although there is no definite source text as the material of translation, the use of English obviously has the nature of translation, which is a very interesting phenomenon in Chinese-American literary writing. Chinese-American writers may write in English, but their voices are unmistakably of Chinese origin, so in a sense their writing can be called translated literature, because it is the product of cultural translation(Sun, 2016:4). When viewing the diversity of cross-cultural communication from a new perspective, it is not difficult to find the commonness and initiatives of various translation activities.

The rise and development of Chinese-American literature is closely related to the socio-cultural context in which the subject of its creation resides. Because the works contain a lot of Chinese elements, writers often involve the Chinese- 
English translation in the creation process. This kind of translation does not refer to the simple conversion on linguistic level, but the cross-temporal reporting and appropriation of Chinese culture, Chinese history and Chinese experience, which is a kind of invisible cultural translation.

\subsection{Influence of Chinese Culture on Chinese American Literature}

Most of the works of Chinese-American writers are written in English, and most of their readers are Americans. Therefore, many Chinese-American writers tend to exhibit their "Chineseness" to potential readers in the process of their cultural translation creation. Because they often hope to create such a cultural translation to effectively avoid the assimilation of vague "Chinese" on them by mainstream society and culture in the United States, so as to maintain their multicultural identity. That explains the "alienated" translation strategy in major translation process. Though ChineseAmerican writers have succeeded in revealing the Chinese symbols and images, which are by no means void of the influence of American culture.

Most Chinese American writers have lived in the United States ever since they were born, which leads to their limited understanding of Chinese culture. In addition, they are deeply influenced by the mainstream American cultural thoughts. Their works tend to interpret Chinese culture in the American way or how the Americans would do. Therefore, to a certain extent, Chinese legends are prone to adaptation and adding with many personalized colors of imagination, which is actually a kind of cultural translation. Hua Mulan, the girl who joined the army for the sake of her father, for example, is basically a household name in China. The Woman Warrior written by Maxine Hong Kingston, depicts the story of Mulan in an attempt to emphasize the power of women, although essentially, the original purpose of Mulan was to be filial to her father. Therefore it still reflects the mentality of the ancient Chinese feudal society.

\subsection{Chinese American Literature as a Form of Cultural Reproduction}

British sociologist Chris Jenks proposed a dynamic view of culture. In his opinion, culture is a process, which is constantly occurring, gradually formed, and continues in the form of reproduction(Jenks, 1993:3). When Chinese American literature absorbs traditional Chinese culture as its inspiration, it is an active practice of reproducing Chinese culture through literary creation and stimulating the modern vitality of traditional Chinese culture. The concept of Cultural reproduction was introduced in the 1970s by Pierre Bourdieu, a contemporary French sociologist in the book La Reproduction. Eléments pour une théorie du système d'enseignement. Bourdieu believed all educational behavior, objectively speaking, is a kind of symbolic violence, is a kind of cultural coercion imposed by coercive power(Bourdieu, 1977:5). In his opinion, the education system colludes with the culture of the social ruling class in the form of symbolic violence to reproduce the culture of this class, so as to ensure the continued dominance of cultural capital and power of this class and thus promote the legitimacy of the social hierarchy structure. While Bourdieu illustrates the reproduction of cultural capital and power in educational field, he built the path of research into cultural reproduction with particular fields of observation point, cultural forms as its content, and the form of discourse as the media, thus revealing the logic of reproduction, which is conducive to exploring the reproduction of culture in literary works. Therefore, the research on cultural reproduction in Chinese American literature should not only focus on the question of cultural authenticity, but also pay more attention to the content, media and purpose of cultural reproduction in Chinese American literature.

\subsection{Traditional Chinese Culture Reflected in Chinese American Literature}

Take Everything I Never Told You by Celeste Ng for example. As an American Writer of Chinese descent, Celeste $\mathrm{Ng}$ was born in the United States, having U.S. citizenship, receiving her education there with English as the primary language, which is typical of Chinese-American writers. The novel tells the tragic story of an interracial family that takes place in a small Ohio town in the 1970s. According to post-colonial theory, in opposition to the subjective "self", the non-Western world outside the "self" is seen as the "the other" in Edward Waefie Said's opinion. Asian skin already defines them as "the other", even if that identity is not recognized by themselves. Yellow-skinned, dark-haired Chinese, even if they long for integrating into the white community, they are still sometimes alienated and marginalized. The "the other" identity was something James was trying to shake off. Not only was he desperate to integrate into the white community, but he wanted his children to do the same. James wanted them to be proactive in integrating into the white community. However, as a white woman, Marilyn was a maverick, and did not like to interact with people. Also, her 
mother objected to their marriage, so the mixed-race family had little interaction with the white community. So it would be unlikely that they would blend in with the crowd. The father, James, because of his Chinese background, he was ostracized by American society. No matter what efforts he made, his identity and the society in which he lived were like oil and water, unable to blend together. He did not want his offspring to make the same mistakes. James almost concentrated all his affection and interest on Lydia, the second and favorite child of the family, for the simple reason that Lydia resembles Marilyn with the same blue eyes and "the same elfish chin and high cheekbones and left-cheek dimple, the same thin-shouldered build"( $\mathrm{Ng}, 2014: 3)$ while the elder son Nath and the younger daughter Hanna take after himself. For this reason, James rarely payed attention to Nath and Hanna.

Family is an important unit based on kinship and each individual in it should fulfill the related obligations as a means to achieve family harmony. Thus, family ethics seem to be even more important in this social environment. Blood relationship is a key factor in Chinese culture, as it is the basis for connecting families, which leads to the traditional family-oriented values in China.

The symbolization and visualization of the narrative of Chinese ritual culture give the story a stable structure and order. In the unbalanced and distorted micro-reality narration, ritual culture narration abstracts a kind of centripetal and grand sacred narration. The construction of narrative synchronic structure and the sorting out of diachronic order form a kind of narrative therapy in literature. From the perspective of connotation, Chinese ritual culture focuses on group consciousness and has certain ethical cohesion. From the symbolic dimension, it helps people to trace back to life events, and corrects the fixed and paranoid thinking mode of the Chinese American group with root culture and filial culture. The Chinese community awakens the cultural collective ritual, finds a sense of belonging, and ultimately establishes a balance between different strengths and different perspectives. In Everything I Never Told You, the family finally gets over their daughter's suicide and finds the courage to live again.

\subsection{Dissolution of Chinese Culture}

Due to the particularity of the birth and growth of Chinese-American writers, they are able to absorb many elements of Chinese culture into their works, but this does not mean that they want to carry forward the Chinese tradition and culture. The Chinese elements in their works are more to reflect the cultural background and foundation of imagination in their creation. After the 1980s, Chinese writers tried to get rid of the ethnic symbols and the Chinese community themes that the original Chinese writers repeatedly appeared in their works. In their works, Chinese culture was diluted and dissolved. Death is repeatedly adopted to predict the disappearance of Chinese culture in the process of selfconstruction among Chinese Americans. Russell Leong in his story Where Do People Live Who Never Die? mentions that Andrew's parents died in China. American Knees featured the death of Raymond's mother. After the nineties of the 20th century, under the trend of globalization, the concept of ethnic groups in the weakened gradually, and the Chinese traditional culture in the eyes of other ethnic groups also have no longer such appeal and mysteriousness, so Chinese American writers' will to use Chinese culture to express the characteristics of the ethnic attributes are also fading. They tend to pursue the expression of individuality and adopt a broader perspective to express Chinese American literature.

\section{Implications on the Spread of Traditional Chinese Culture overseas}

The influence and inspiration of Chinese American literary writing on the reproduction of Chinese traditional culture are mainly reflected in two aspects. First, It provides useful references for the reproduction strategies and communication modes of traditional Chinese culture as to how to gain recognition and appreciation among western critics and common readers. First of all, the appeal comes from the exotic impression. Writers can take from profound Chinese culture materials that can be applied in their writings. Contemporary Chinese American writers have integrated a great deal of Chinese culture into their narratives, and presented a certain tendency of choice, that is to highlight the heterogeneity between Chinese and American cultures. Cultural symbols such as sacrificial ceremony, funeral ceremony, food, tea, blood and so on with Chinese elements in an attempt to draw readers' attention to China's filial piety tradition, root culture and ethical culture. Chinese American writers not only skillfully play to the advantage of ethnic writers' cultural background, but also cater to the American reading community's expectation and curiosity for foreign cultures. Secondly, the writers excellent writing skills render the plot strong readability, echoing the shared 
feelings of mankind, thus arouse the resonance of the general public. Successful Chinese American literary works are the products of foreignization and domestication.

However, there are also some negative effects of adopting traditional Chinese culture into the writing of Chinese American literature. First, most Chinese American writers are of Chinese descent, but they have been born and raised in America, received education and lived there, inevitably they are mostly influenced by western culture in their outlook on life. Their perception of the oriental culture is also influenced by the mainstream American society. Thus they often touch upon oriental culture by diminishing it, while praise western culture so as to gain recognition among American readers. Secondly, Chinese culture boasts such long history and comprehensive connotation that it is difficult even for Chinese people to fully appreciate. While most Chinese American writers live far away from China and have been deeply influenced by western culture ever since they are born. They lack a comprehensive and profound understanding of eastern culture. Because they faced the pressure of Orientalism in American society when they created their works, they could only depict oriental culture with their own imagination, which made their works lose their objectivity.

\section{Conclusion}

Since its emergence, Chinese American literature witnessed its golden era in the late 1980s. New generation of Chinese American writers have a strong Chinese complex, although it is undeniable that some of the Chinese traditional cultural symbol in their writings have been adapted, restructured and integrated, and sometimes even distorted to accommodate the plot or characters. It is without doubt that through their writing, Chinese ethnicity is revealed to the full performance. Traditional Chinese culture provides the possibility for Chinese American writers to write metaphorically, which not only increases the readers' interest of reading, but also add weight to the historical significance of their work. Traditional Chinese culture has provided a solid foundation and a great source of inspiration for those writers. Through the writing of Chinese American writers, the imagined homeland of Chinese Americans is revealed. They use their pens to create heroes in the new era, and these characters are powerful tools to reconstruct Chinese American history, promote Chinese American culture, and reshape the image of Chinese Americans. From the perspective of cultural translation, Chinese American writers have applied Chinese traditional culture to their works and achieved success in the target audience, which provides effective solutions and rich experience for the dissemination of traditional Chinese culture.

\section{Reference}

1. Bassnett Susan, Lefevere André. Constructing Cultures: Essays on Literary Translation[M].Shanghai:Shanghai Foreign Language Education Press, 2001.

2. Bourdieu Pierre, Jean-Claude Passeron. Reproduction in Education, Society and Culture[M]. Richard Nice trans. London: Sage Publications, 1977.

3. Jenks Chris(ed.).The Analytic Bases of Cultural Reproduction Theory in Cultural Reproduction[M]. London:Routledge, 1993.

4. Lefevere André. Translation,History and Culture[M]. London: Routledge,1992.

5. Ng, Celeste. Everything I Never Told You, London: Penguin Books, 2015.

6. Sun Yifeng. Culture and Translation[M]. Beijing: Peking University Press, 2016.

7. Xie Tianzhen. Contemporary Theories in Foreign Translation Studies: An Introductory Reader(Second Edition)[M]. Tianjin:Nankai University Press, 2018. 